\title{
Vanadium(II)-diamine Complexes: Synthesis, UV-Visible, Infrared, Thermogravimetry, Magnetochemistry and INDO/S Characterisation
}

\author{
Antonio C. Niedwieski ${ }^{a}$, Peter B. Hitchcock ${ }^{b}$, Joaquim D. Da Motta Neto ${ }^{a}$, Fernando Wypych ${ }^{a}$, \\ G. Jeffery Leigh ${ }^{b}$ and Fábio S. Nunes ${ }^{*, a}$ \\ ${ }^{a}$ Departamento de Química, Universidade Federal do Paraná, Centro Politécnico, CP 19081, \\ 81531-990 Curitiba - PR, Brazil \\ ${ }^{b}$ School of Chemistry, Physics and Environmental Science, University of Sussex, Brighton, BN1 9QJ, UK
}

\begin{abstract}
A série de complexos de vanádio(II), $\left[\mathrm{VCl}_{2}\left(\right.\right.$ diamina) $\left.{ }_{2}\right]$ (diamina $=$ dmeda: $N, N$ '-dimetiletano1,2-diamina, deeda: $N, N^{\prime}$-dietiletano-1,2-diamina, tmeda: $N, N, N^{\prime}, N^{\prime}$-tetrametiletano-1,2-diamina, dieda: $N, N^{\prime}$-diisopropiletano-1,2-diamina, teeda: $N, N, N^{\prime}, N^{\prime}$-tetraetiletano-1,2-diamina, dtbeda: $N, N^{\prime}$ ditert-butiletano-1,2-diamina and dfeda: $N, N$ '-difeniletano-1,2-diamina) foi preparada e caracterizada por análise elementar, espectrometria de massas (FAB), espectroscopia de absorção no UV-visível e infravermelho, termogravimetria e magnetoquímica. O complexo $\left[\mathrm{VCl}_{2}(\text { deeda })_{2}\right]$ foi caracterizado por difração de raios $\mathrm{X}$ de monocristal. Alguns destes compostos podem ser convertidos no cátion trinuclear $\left[\mathrm{V}_{3}(\mu-\mathrm{Cl})_{3}\left(\mu_{3}-\mathrm{Cl}\right)_{2}(\text { diamina })_{3}\right]^{+}$por reação com $\left[\mathrm{V}_{2}(\mu-\mathrm{Cl})_{3}(\text { thf })_{3}\right]^{+}$em condições brandas. A estabilidade dos complexos $\left[\mathrm{VCl}_{2}(\text { diamina })_{2}\right]$ varia com a natureza da diamina e correlaciona-se com parametros de campo cristalino, frequências de modos vibracionais, as temperaturas de decomposição e com as energias dos orbitais de fronteira. Uma nova rota de síntese de $\left[\mathrm{V}_{3}(\mu-\mathrm{Cl})_{3}\left(\mu_{3}-\right.\right.$ $\left.\mathrm{Cl})_{2}(\text { diamina })_{3}\right]^{+}$é apresentada e permite um melhor controle do caminho da reação e evita a formação de subprodutos indesejáveis.
\end{abstract}

The synthesis, spectroscopic characterisation and reactivity of a series of vanadium(II) complexes, $\left.\left[\mathrm{VCl}_{2} \text { (diamine) }\right)_{2}\right]$ (diamine = dmeda: $N, N^{\prime}$-dimethylethane-1,2-diamine, deeda: $N, N$ '-diethylethane1,2-diamine, tmeda: $N, N, N^{\prime}, N^{\prime}$-tetramethylethane-1,2-diamine, dieda: $N, N^{\prime}$-diisopropylethane-1,2diamine, teeda: $N, N, N^{\prime}, N^{\prime}$-tetraethylethane-1,2-diamine, dtbeda: $N, N^{\prime}$-ditert-butylethane-1,2-diamine and dfeda: $N, N^{\prime}$-diphenylethane-1,2-diamine) are reported. Some of these complexes can be converted into the trinuclear cation $\left[\mathrm{V}_{3}(\mu-\mathrm{Cl})_{3}\left(\mu_{3}-\mathrm{Cl}\right)_{2}(\text { diamine })_{3}\right]^{+}$through the reaction with $\left[\mathrm{V}_{2}(\mu-\mathrm{Cl})_{3}(\mathrm{thf})_{3}\right]^{+}$ under mild conditions. The compounds were characterised by microanalysis, positive ion FAB mass spectrometry, UV-visible and infrared spectroscopies, thermogravimetric analysis and magnetic moment measurements in the solid state. We characterised fully by single-crystal X-ray diffraction analysis the complex $\left[\mathrm{VCl}_{2}(\text { deeda })_{2}\right]$. The stability of $\left[\mathrm{VCl}_{2}(\text { diamine })_{2}\right]$ as they vary with the different diamines is correlated with crystal field and infrared parameters along with decomposition temperatures and the calculated molecular orbital energies. We also presented a new synthetic route to prepare $\left[\mathrm{V}_{3}(\mu-\mathrm{Cl})_{3}\left(\mu_{3}-\mathrm{Cl}\right)_{2}(\text { diamine })_{3}\right]^{+}$which allows a better control of the reaction pathway, avoiding the formation of undesired redox reaction products.

Keywords: vanadium(II) diamine complexes, crystal field analysis, X-ray crystal structure, infrared spectroscopy, thermochemistry

\section{Introduction}

It is now known that vanadium nitrogenases are very similar in structural, electronic and catalytic properties to the well-studied molybdenum nitrogenases. ${ }^{1}$ For example, both Mo and V enzymes contain three different types of

* e-mail: fsnunes@quimica.ufpr.br metal aggregate all involved in the multistep electron transfer process characteristic of the enzyme activity. The iron-vanadium cofactor ( $\mathrm{FeVco}$ ), the $\mathrm{V}$-analogue of the structurally characterised octanuclear FeMoco found in Mo-nitrogenases, is believed to be part of the substrate binding, activation and reduction site. These findings have given rise to a search for polynuclear complexes of vanadium and iron as models for the biological catalysts of nitrogen fixation. ${ }^{2}$ 
Earlier results from our and other groups showed that trans $-\left[\mathrm{VCl}_{2}(\text { tmeda) })_{2}\right]$ (tmeda $=N, N, N^{\prime}, N^{\prime}$-tetramethylethane-1,2-diamine $)^{3}$ is a good starting material for the synthesis of $\left[\mathrm{V}_{3}(\mu-\mathrm{Cl})_{3}\left(\mu_{3}-\mathrm{Cl}\right)_{2}(\text { tmeda })_{3}\right]^{+}$through a mechanism triggered by chloride loss (Scheme 1). ${ }^{4}$ However, the subsequent steps in this mechanism are not known. This prompted us to study the effect of substitution of the diamine at the vanadium centre.

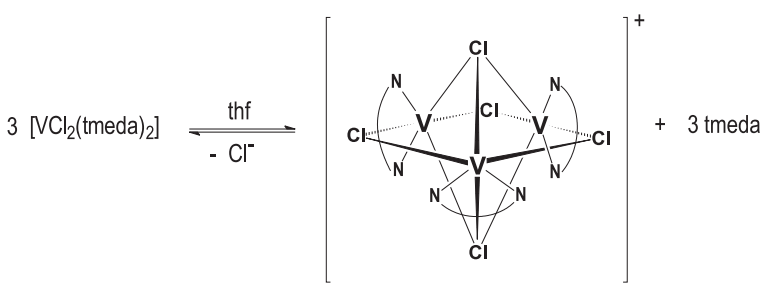

Scheme 1.

Herein we describes the synthesis and characterisation of new vanadium(II)-bidentate diamine adducts formulated as $\left[\mathrm{VCl}_{2}(\text { diamine })_{2}\right]$ or $\left.\left[\mathrm{V}_{3} \mathrm{Cl}_{5} \text { (diamine) }\right)_{3}\right]^{+}$, and a systematic investigation of the influence of the diamine on the stabilisation of these complexes. The results correlate very well with the electronic structures of the diamines, the energies of the d-d transitions, the V-N(diamines) stretching frequencies and the temperature of loss of the diamine.

\section{Glossary of most used abbreviations}

dmeda $=N, N^{\prime}$-dimethylethane-1,2-diamine; deeda $=$ $N, N^{\prime}$-diethylethane-1,2-diamine; tmeda $=N, N, N^{\prime}, N^{\prime}$ tetramethylethane-1,2-diamine; dieda $=N, N^{\prime}$-diisopropylethane-1,2-diamine; teeda $=N, N, N^{\prime}, N^{\prime}$-tetraethylethane1,2-diamine; dtbeda: $N, N^{\prime}$ '-ditert-butylethane-1,2-diamine and dfeda: $N, N^{\prime}$-diphenylethane-1,2-diamine $\left[\mathrm{VCl}_{2}\right.$ (tmeda) $\left.{ }_{2}\right]$ (1); $\left[\mathrm{VCl}_{2}(\mathrm{dmeda}){ }_{2}\right](\mathbf{2}) ;\left[\mathrm{VCl}_{2}(\text { deeda })_{2}\right](\mathbf{3})$; $\left[\mathrm{VCl}_{2}\right.$ (dieda) $\left.{ }_{2}\right]$ (4); $\left.\left[\mathrm{VCl}_{2} \text { (dtbeda)(thf) }\right)_{2}\right] \cdot$ thf $(\mathbf{5}) ;\left[\mathrm{V}_{3}(\mu\right.$ $\left.\mathrm{Cl})_{3}\left(\mu_{3}-\mathrm{Cl}\right)_{2}(\mathrm{tmeda})_{3}\right]\left[\mathrm{B}\left(\mathrm{C}_{6} \mathrm{H}_{5}\right)_{4}\right](\mathbf{6}) ;\left[\mathrm{V}_{3}(\mu-\mathrm{Cl})_{3}\left(\mu_{3}-\mathrm{Cl}\right)_{2}\right.$ (teeda) $\left.{ }_{3}\right] \mathrm{Cl}(\mathbf{7}) ;\left[\mathrm{V}_{3}(\mu-\mathrm{Cl})_{3}\left(\mu_{3}-\mathrm{Cl}\right)_{2}(\text { deeda })_{3}\right]\left[\mathrm{B}\left(\mathrm{C}_{6} \mathrm{H}_{5}\right)_{4}\right](\mathbf{8})$.

\section{Experimental}

General

All operations were carried out under an inert atmosphere with the use of standard Schlenk techniques. Solvents were dried by standard procedures and distilled twice under $\mathrm{N}_{2}$ prior to use. ${ }^{5}$

\section{Measurements}

FAB mass spectra were recorded by Dr. A. Abdul Sada
(School of Chemistry, Physics and Environmental Sciences, University of Sussex), on a VG Autospec spectrometer (Fisons Instruments), equipped with a CsI gun at $25 \mathrm{kV}$ (SIMS technique) or on a Kratos MS80RF machine with xenon at $8 \mathrm{kV}$ (FAB technique). In both cases, 3-nitrobenzyl alcohol was used as the matrix.

Electronic spectra in the UV-vis range (190-820 nm) were obtained on a Hewlett-Packard Model 8452A diodearray spectrophotometer in thf and dichloromethane solutions.

${ }^{1} \mathrm{H}-\mathrm{NMR}$ spectra for complex 4 were recorded by Mr. Cesar A. Tischer (Department of Biochemistry, Universidade Federal do Paraná) on a Bruker DRX-400 machine at $300 \mathrm{~K}$. The NMR solvent (thf- $\mathrm{d}_{8}$ containing $1 \% \mathrm{v} / \mathrm{v}$ of tetramethylsilane, Aldrich) was degassed by the freeze-pump-thaw technique.

Magnetic moment and magnetic susceptibility measurements were carried out in the solid state at room temperature using a MKII magnetic susceptibility balance from Johnson-Matthey. Corrections for the diamagnetism of the ligands were applied by the use of Pascal constants. ${ }^{6}$

Thermogravimetric curves were performed under $\mathrm{N}_{2}(\mathrm{~g})$ from 20 to $1000{ }^{\circ} \mathrm{C}$ at the rate of $10^{\circ} \mathrm{C}$ min on a NETZSCH Simultaneous Thermal Analyser (STA) 409EP.

\section{Theoretical calculations}

For the evaluation of electronic spectra, we have used the Intermediate Neglect of Differential Overlap for spectroscopy (INDO/S) technique of Zerner and coworkers ${ }^{7}$ as described elsewhere. ${ }^{8}$ The two-centre, one-electron integrals for vanadium were chosen as $\beta(4 \mathrm{~s})=-1.0 \mathrm{eV}$ and $\beta(3 \mathrm{~d})=-20.0 \mathrm{eV}$. ${ }^{9}$ The reference determinants were obtained using the restricted open shell Hartree-Fock (ROHF) procedure of Edwards and Zerner. ${ }^{10}$ By doing so we ensure that the wavefunction is a spin eigenstate, appropriate for prediction of spectroscopy. Due to the expected severe multireference effects within the central vanadium cluster, ${ }^{9}$ the set of starting orbitals had to be obtained with the configuration-averaged Hartree-Fock procedure (CAHF). ${ }^{11}$ All calculations were carried out with the ZINDO code, ${ }^{12}$ running under the FreeBSD operational system in a CyberMax personal computer at the Department of Chemistry, UFPR.

\section{$X$-ray crystallographic measurements}

A suitable pink-purplish crystal of $\left[\mathrm{VCl}_{2}(\text { deeda })_{2}\right](0.20$ $\mathrm{x} 0.10 \times 0.05 \mathrm{~mm}^{3}$ ) was mounted on a glass fiber and cooled to $173 \mathrm{~K}$ on a Nonius Kappa CCD area detector diffractometer at the School of Chemistry, Physics and 
Environmental Science (CPES), University of Sussex, UK. The crystal diffraction intensity fell off rapidly with increasing theta. The structure was solved by direct methods using the program package WinGX $\mathrm{X}^{13}$ and refined by fullmatrix least-squares on $\mathrm{F}^{2}$ with SHELXL-97. ${ }^{14}$ Drawings were made with ORTEP3 for Windows. ${ }^{13}$ An absorption correction was carried out with MULTISCAN ( $\mathrm{T}_{\max } 0.979$ and $\mathrm{T}_{\min }$ 0.850). A summary of data collection and refinement is in Table 1.

Microanalyses were done under nitrogen by MEDAC Ltd. Laboratories in Egham, Surrey, UK.

\section{Materials}

All reagents were supplied by Aldrich Chemical Co. Solvents were purchased from Carlo Erba. Vanadium(III) chloride and sodium tetraphenylborate were used as supplied. Zinc granules were activated by a $2 \%(\mathrm{v} / \mathrm{v})$ hydrochloric acid solution before use. Liquid diamines were refluxed over sodium and distilled under dinitrogen.

\section{Syntheses}

The starting materials $\left[\mathrm{V}_{2} \mathrm{Cl}_{3}(\text { thf })_{6}\right]_{2}\left[\mathrm{Zn}_{2} \mathrm{Cl}_{6}\right]^{15}$ and $\left[\mathrm{V}_{2} \mathrm{Cl}_{3}(\mathrm{thf})_{6}\right]\left[\mathrm{B}\left(\mathrm{C}_{6} \mathrm{H}_{5}\right)_{4}\right]^{16}$ were prepared as described. $\left[\mathrm{VCl}_{2}\right.$ (tmeda) ${ }_{2}$, (1), was synthesised by a standard literature method. ${ }^{3}$ The preparation of $\left[\mathrm{VCl}_{2}(\mathrm{dmeda})_{2}\right]$ (2) was first reported by Hitchcock and co-workers from $\mathrm{VCl}_{2}(\mathrm{EtOH})_{2}$ and dmeda in thf. ${ }^{4}$

Dichlorobis(N,N'-dimethylethane-1,2-diamine) vanadium(II), $\left[\mathrm{VCl}_{2}\left(\right.\right.$ dmeda) $\left.{ }_{2}\right](\mathbf{2}) .\left[\mathrm{V}_{2} \mathrm{Cl}_{3} \text { (thf) }\right]_{2}\left[\mathrm{Zn}_{2} \mathrm{Cl}_{6}\right]$ $(1.0 \mathrm{~g}, 0.62 \mathrm{mmol})$ was suspended in $40 \mathrm{~mL}$ of thf and heated under reflux for $c a .20 \mathrm{~min}$, after which dmeda (1.32 mL, $12.4 \mathrm{mmol}$ ) was added. The solution changed from light green to light purple followed by an immediate precipitation. After cooling to room temperature, a light- purple solid was collected by filtration, washed with thf and dried under vacuum. The yield was $80 \%$. Anal. Calcd for $\mathrm{C}_{8} \mathrm{H}_{20} \mathrm{~N}_{4} \mathrm{Cl}_{2} \mathrm{~V}$ : C, 32.2; H, 8.11; N, $18.8 \%$. Found: C, 31.6; H, 8.00; N, $18.5 \%$. FAB-MS ( $\mathrm{m} / z$, rel. int.): 297 (2\%, $\left.\left\{\mathrm{VCl}_{2}(\mathrm{dmeda})_{2}\right\}^{+}\right) ; 261\left(10 \%,\left\{\mathrm{VCl}(\text { dmeda })_{2}\right\}^{+}\right) \cdot \mu_{\text {eff }}=$ $3.67 \mu_{\mathrm{B}}$.

Dichlorobis $(N, N$ '-diethylethane-1,2-diamine) vanadium(II), $\left[\mathrm{VCl}_{2}(\text { deeda) })_{2}\right](3)$. $\left[\mathrm{V}_{2} \mathrm{Cl}_{3}(\text { thf })_{6}\right]_{2}\left[\mathrm{Zn}_{2} \mathrm{Cl}_{6}\right](1.0$ $\mathrm{g}, 0.62 \mathrm{mmol}$ ) was suspended in $40 \mathrm{~mL}$ of thf and heated under reflux for ca. $20 \mathrm{~min}$, after which deeda $(1.78 \mathrm{~mL}$, $12.4 \mathrm{mmol}$ ) were added. The solution changed from light green to purple. After cooling to room temperature the sample was stored at $-15^{\circ} \mathrm{C}$ for $3 \mathrm{~h}$. Purple crystals were collected by filtration, washed with hexane and dried under vacuum. The yield was $68 \%$. Anal. Calcd for $\mathrm{C}_{12} \mathrm{H}_{32} \mathrm{~N}_{4} \mathrm{Cl}_{2} \mathrm{~V}$ : C, 40.9; H, 9.16; N, 15.9 \%. Found: C, 40.6; H, 8.40; N, 15.8\%. FAB-MS: $m / z 354\left(7 \%,\left\{\mathrm{VCl}_{2}(\text { deeda })_{2}\right\}^{+}\right) \cdot \mu_{\text {eff }}=3.72$ $\mu_{\mathrm{B}}$.

Dichlorobis(N,N'-diisopropylethane-1,2-diamine) $\operatorname{vanadium}(I I),\left[\mathrm{VCl}_{2}(\text { dieda })_{2}\right](\mathbf{4}) .\left[\mathrm{V}_{2} \mathrm{Cl}_{3}(\text { thf })_{6}\right]_{2}\left[\mathrm{Zn}_{2} \mathrm{Cl}_{6}\right]$ $(1.1 \mathrm{~g}, 0.62 \mathrm{mmol})$ was suspended in $50 \mathrm{~mL}$ of thf and heated under reflux for ca. $20 \mathrm{~min}$, after which dieda (2,4 $\mathrm{mL}, 13.5 \mathrm{mmol})$ were added. The solution changed from light green to green bluish. After cooling to room temperature the sample was stored at $-15^{\circ} \mathrm{C}$ for $3 \mathrm{~h}$. Violet crystals were collected by filtration, washed with hexane and dried under vacuum. The yield was $65 \%$. Anal. Calcd for $\mathrm{C}_{16} \mathrm{H}_{40} \mathrm{~N}_{4} \mathrm{Cl}_{2} \mathrm{~V}: \mathrm{C}, 46.5 ; \mathrm{H}, 10.0 ; \mathrm{N}, 13.7 \%$. Found: C, 46.4; H, 9.91; N, 13.7\%. FAB-MS: $m / z 409$ (1\%, $\left.\left\{\mathrm{VCl}_{2}(\text { dieda })_{2}\right\}^{+}\right)$and $\left(1 \%,\left\{\mathrm{VCl}_{2}(\text { dieda })\right\}^{+}\right), \mu_{\text {eff }}=3.72 \mu_{\mathrm{B}}$.

Dichloro(N,N'-ditert-butylethane-1,2-diamine)bistetrahydrofuranvanadium(II) $\left[\mathrm{VCl}_{2}(\right.$ dtbeda $\left.)(\text { thf })_{2}\right] \cdot \operatorname{thf}(\mathbf{5})$. The addition of dtbeda (2.65 $\mathrm{mL}, 12.4 \mathrm{mmol})$ to a light green suspension of $\left[\mathrm{V}_{2} \mathrm{Cl}_{3}(\mathrm{thf})_{6}\right]_{2}\left[\mathrm{Zn}_{2} \mathrm{Cl}_{6}\right](1.0 \mathrm{~g}, 0.62$

Table 1. Crystal data and structure refinement for trans-[ $\left[\mathrm{VCl}_{2}(\mathrm{deeda})_{2}\right]$

\begin{tabular}{|c|c|c|c|}
\hline Empirical formula & $\mathrm{C}_{12} \mathrm{H}_{32} \mathrm{Cl}_{2} \mathrm{~N}_{4} \mathrm{~V}$ & $\mathrm{~V}, \AA^{3}$ & $437.8(2)$ \\
\hline FW & 354.26 & $\mathrm{~F}(000)$ & 189 \\
\hline $\mathrm{T}$ & $173(2) \mathrm{K}$ & $\mathrm{Z}$ & 1 \\
\hline$\lambda(\mathrm{Mo}, \mathrm{K} \alpha), \AA$ & 0.71073 & $\rho_{\text {calcd }}, \mathrm{mg} / \mathrm{m}^{3}$ & 1.34 \\
\hline Crystal system & Triclinic & $\mu, \mathrm{mm}^{-1}$ & 0.87 \\
\hline Space group & $\mathrm{P}($ No. 2$)$ & $\theta$ range, deg & 3.74 to 24.97 \\
\hline $\mathrm{a}, \AA$ & $6.7408(13)$ & Reflections collected & 2897 \\
\hline $\mathrm{b}, \AA$ & $7.9366(19)$ & Independent reflections & 1503 \\
\hline $\mathrm{c}, \AA$ & $8.302(2)$ & Reflections $\mathrm{I}>2 \sigma_{\mathrm{I}}$ & 954 \\
\hline$\alpha, \operatorname{deg}$ & $84.345(11)$ & $\mathrm{R} 1, \mathrm{wR}_{2}\left(\mathrm{I}>2 \sigma_{\mathrm{I}}\right)$ & $0.071,0.162$ \\
\hline$\beta$, deg & $84.072(14)$ & $\mathrm{R}$ indices (all data) & $0.120,0.189$ \\
\hline$\gamma, \operatorname{deg}$ & $84.279(13)$ & & \\
\hline
\end{tabular}

Refinement method: Full-matrix least-squares on $\mathrm{F}^{2} ; \mathrm{R} 1$ and $w \mathrm{R} 2$ were calculated as defined by the SHELX1-97 program. ${ }^{14}$ 
mmol) in refluxing thf $(40 \mathrm{~mL})$ gave a greenish blue solution, with immediate precipitation of a very fine pale green solid. After cooled to room temperature, it was filtrated and kept for 4 days at $-20{ }^{\circ} \mathrm{C}$. Upon this time, we were able to isolate greenish blue crystals. The yield was 50\%. Anal. calcd. for $\mathrm{C}_{22} \mathrm{H}_{46} \mathrm{~N}_{2} \mathrm{Cl}_{2} \mathrm{O}_{3} \mathrm{~V}$ : C, 51.97; H, 9.12; N, 5.51\%. Found: C, 52.25; H, 10.16; N, 7.13. FAB-MS: $m / z 381\left(25 \%,\left\{\mathrm{VCl}_{2}(\text { tbeda })(\text { thf })_{2}\right\}^{+}\right)$, tbeda $=$terc butylethylenediamine. $\mu_{\text {eff }}=3.47 \mu_{\mathrm{B}}$.

Tri $(\mu$-chloro $)$ bis $\left(\mu_{3}\right.$-chloro $)$ tris $\left(N, N, N^{\prime}, N\right.$ '-tetramethylethane-1,2-diamine)vanadium(II) tetraphenylborate, $\left[\mathrm{V}_{3}(\mu-C l)_{3}\left(\mu_{3}-C l\right)_{2}(\text { tmeda })_{3}\right]\left[B\left(C_{6} H_{5}\right)_{4}\right](6) .\left[\mathrm{V}_{2} \mathrm{Cl}_{3}(\text { thf })_{6}\right]$ $\left(\mathrm{B}\left(\mathrm{C}_{6} \mathrm{H}_{5}\right)_{4}\right)(2.1 \mathrm{~g}, 2.2 \mathrm{mmol})$ was dissolved in $20 \mathrm{~mL}$ of thf followed by a filtration by celite. The filtrate was mixed with a fresh and clear solution of $\left[\mathrm{VCl}_{2}(\mathrm{tmeda})_{2}\right](0,78 \mathrm{~g}$ $2,2 \mathrm{mmol})$ in $30 \mathrm{~mL}$ of thf containing one equivalent $(0,34$ $\mathrm{mL}, 2,2 \mathrm{mmol}$ ) of tmeda. $50 \mathrm{~mL}$ of hexane was slowly added to the resulting green-blue solution and the mixture was allowed to stand at room temperature for 3 days. $1.6 \mathrm{~g}$ of a green powder was recovered and recrystallized from thf, yielding $1.0 \mathrm{~g}$ after slow diffusion of a hexane layer. The yield was $60 \%$. Anal. Calcd for $\mathrm{C}_{42} \mathrm{H}_{68} \mathrm{~N}_{6} \mathrm{BCl}_{5} \mathrm{~V}_{3}: \mathrm{C}$, 50.6; H, 6.87; N, $8.42 \%$. Found: C, 50.8; H, 6.90; N, 8.40. FAB-MS: $m / z 678\left(20 \%,\left[\mathrm{~V}_{3} \mathrm{Cl}_{5}(\text { tmeda })_{3}\right]^{+}\right) .{ }^{1} \mathrm{H}-\mathrm{NMR}, \delta$ (ppm), thf-d $\mathrm{d}_{8}: 6.71,6.86,7.29$ (tetraphenylborate); 10.4, $11.1\left(\mathrm{~N}-\mathrm{CH}_{3}\right.$ and $\mathrm{N}-\mathrm{CH}_{2}-$, tmeda). This was identical to the spectrum of 4 prepared by the halide-abstraction route (see Discussion). ${ }^{4} \mu_{\text {eff }}=1.01 \mu_{\mathrm{B}}$ per vanadium atom.

Tri( $\mu$-chloro $)$ bis $\left(\mu_{3}\right.$-chloro $) \operatorname{tris}\left(N, N, N^{\prime}, N^{\prime}\right.$ tetraethylethane-1,2-diamine)vanadium(II) chloride, $\left[V_{3}(\mu-C l)_{3}\left(\mu_{3}-C l\right)_{2}(\text { teeda })_{3}\right] C l(7) .\left[\mathrm{V}_{2} \mathrm{Cl}_{3}(\text { thf })_{6}\right]_{2}\left[\mathrm{Zn}_{2} \mathrm{Cl}_{6}\right](1.0$ $\mathrm{g}, 0.62 \mathrm{mmol}$ ) was suspended in $40 \mathrm{~mL}$ of thf and kept under reflux for ca. $20 \mathrm{~min}$, after which teeda $(2.62 \mathrm{~mL}$, $12.4 \mathrm{mmol}$ ) was added. The solution changed from light green to deep green. The precipitation started while the system was still warm. A light-green solid was collected by filtration, washed with hexane and dried under vacuum. The yield was $63 \%$. Anal. Calcd for $\mathrm{C}_{30} \mathrm{H}_{72} \mathrm{~N}_{6} \mathrm{~V}_{3} \mathrm{Cl}_{6}$ : C, 40.8; H, 8.22; N, $9.52 \%$. Found: C, 40.3; H, 8.30; N, 9.54\%. FAB-MS: $m / z 846\left(90 \%,\left[\mathrm{~V}_{3} \mathrm{Cl}_{5}(\text { teeda })_{3}\right]^{+}\right) \cdot \mu_{\text {eff }}=1.47 \mu_{\mathrm{B}}$. per vanadium atom.

Tri( $\mu$-chloro $)$ bis $\left(\mu_{3}\right.$-chloro $)$ tris( $N, N$ '-diethylethane-1,2diamine)vanadium(II) tetraphenylborate, $\left[V_{3}(\mu-C l)_{3}\left(\mu_{3}-\right.\right.$ $\left.\mathrm{Cl})_{2}(\text { deeda })_{3}\right]\left[\mathrm{B}\left(\mathrm{C}_{6} \mathrm{H}_{5}\right)_{4}\right](\mathbf{8})$. To a clear green solution of $\left.\left[\mathrm{V}_{2} \mathrm{Cl}_{3} \text { (thf }\right)_{6}\right]_{2}\left(\mathrm{~B}\left(\mathrm{C}_{6} \mathrm{H}_{5}\right)_{4}\right)(1.75 \mathrm{~g}, 1.82 \mathrm{mmol})$ in $40 \mathrm{~mL}$ of thf , was added $\left[\mathrm{VCl}_{2}(\text { deeda })_{2}\right](0.65 \mathrm{~g}, 1.82 \mathrm{mmol}$ suspended in $30 \mathrm{~mL}$ of thf) and $0.26 \mathrm{~mL}(1.82 \mathrm{mmol})$ of deeda. The reaction mixture turned blue, followed by precipitation (within $10 \mathrm{~min}$ ) of a light blue solid. The product was recovered by filtration, washed with a mixture of thf and hexane $(1: 1 \mathrm{v} / \mathrm{v})$ and dried under vacuum. The solid was extremely air sensitive, turning rapidly to deep purple (characteristic of vanadium species in higher oxidation states) upon drying.

\section{Results and Discussion}

Crystal and molecular structure of trans- $\left[\mathrm{VCl}_{2}(\text { deeda })_{2}\right](\mathbf{3})$

An ORTEP view of the complex along with the atom numbering scheme is shown in Figure 1. Crystallographic data are presented in Table 1 and selected bond distances and angles are listed in Table 2. A comparison with mean molecular dimensions reported for similar vanadium(II)diamine adducts is shown in Table 3. In 3, the triclinic unit cell (space group $\mathrm{P} \overline{1}$, number 2 ) contains only one discrete $\left[\mathrm{VCl}_{2}(\text { deeda })_{2}\right]$ molecule. The vanadium(II) ion occupies an octahedral environment with the chloride ligands bound axially to it at a distance of $2.4936(14) \AA$ in a transgeometry. The same configuration was reported for $\left[\mathrm{VX}_{2}(\text { tmeda })_{2}\right](\mathrm{X}=\mathrm{Cl}$ or $\mathrm{Br})$ with the $\mathrm{V}$-X distance at 2.487(1) and 2.656(1), respectively., ${ }^{3,4}$ Complex 3 has a V$\mathrm{N}$ bond which is at least $0.058 \AA$ shorter than the corresponding dimension in $\left[\mathrm{VCl}_{2}(\text { tmeda) })_{2}\right]$ (1) and shows the smallest N(1)-V-N(2) angle (Table 3), taking the different

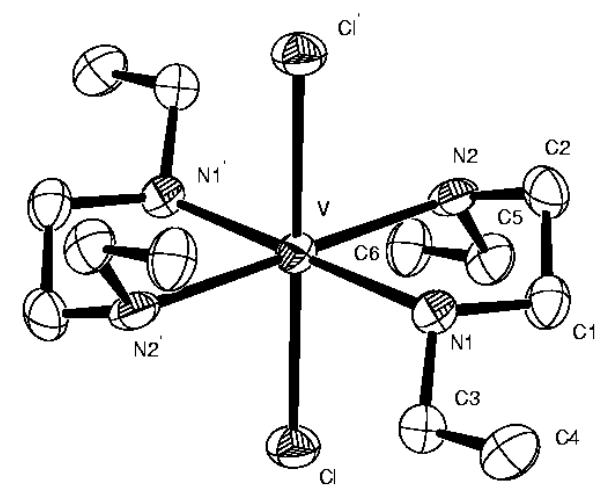

Figure 1. ORTEP drawing of $\left[\mathrm{VCl}_{2}(\text { deeda })_{2}\right]$ with the labelling scheme. Thermal ellipsoids drawn at the $50 \%$ probability level.

Table 2. Selected bond lengths $[\AA]$ and angles $\left[{ }^{\circ}\right]$ for trans$\left[\mathrm{VCl}_{2}(\text { deeda) })_{2}\right]$ (complex 3). Symmetry transformations used to generate equivalent atoms: ' $-\mathrm{x},-\mathrm{y}+1,-\mathrm{z}+1$

\begin{tabular}{ll}
\hline $\mathrm{V}-\mathrm{N}(1)$ & $2.228(5)$ \\
$\mathrm{V}-\mathrm{N}(2)$ & $2.260(5)$ \\
$\mathrm{V}-\mathrm{Cl}$ & $2.4936(14)$ \\
$\mathrm{N}(1)-\mathrm{V}-\mathrm{N}(2)$ & $80.42(18)$ \\
$\mathrm{N}(1)-\mathrm{V}-\mathrm{Cl}$ & $90.47(14)$ \\
$\mathrm{N}(2)-\mathrm{V}-\mathrm{Cl}$ & $93.63(13)$ \\
\hline
\end{tabular}


Table 3. Selected mean dimensions for $\left[\mathrm{VX}_{2}(\text { diamine })_{2}\right]$

\begin{tabular}{llll}
\hline Mean Dimension & \multicolumn{3}{c}{ Halide/Diamine } \\
& $\mathrm{Cl} / \mathrm{tmeda}^{3}$ & $\mathrm{Br}^{\mathrm{t} \text { tmeda }}{ }^{4}$ & $\mathrm{Cl} / \mathrm{deeda}$ \\
\hline $\mathrm{V}-\mathrm{X} / \AA$ & $2.487(1)$ & $2.656(1)$ & $2.4936(14)$ \\
$\mathrm{V}-\mathrm{N} / \AA$ & $2.319(1)$ & $2.318(6)$ & $2.244(5)$ \\
$\mathrm{N}(1)-\mathrm{V}-\mathrm{N}(2) /{ }^{\circ}$ & $81.44(7)$ & $81.0(3)$ & $80.42(18)$ \\
$\mathrm{X}-\mathrm{V}-\mathrm{N}(1,2) /{ }^{\circ}$ & $89.96(1)$ & $90.0(1)$ & $92.05(14)$ \\
\hline
\end{tabular}

temperatures of data collection into consideration (130K for $\mathbf{1}^{3}$ and $173 \mathrm{~K}$ for $\mathbf{3}$ ). This implies a stronger $\mathrm{V}-\mathrm{N}$ bond in 3 consistent with the stability of their mononuclear complexes discussed below.

Characterisation of the mononuclear $\left.\left[\mathrm{VCl}_{2} \text { (diamine }\right)_{2}\right]$ and the trinuclear $\left[V_{3}(\mu-C l)_{3}\left(\mu_{3}-C l\right)_{2}(\text { diamine })_{3}\right]^{+}$ complexes

The elemental analyses together with the mass spectra and the magnetic moments of compounds 2, 3, 4 and 5 support the mononuclear formulation. Both the tmeda ${ }^{3}$ and the deeda complexes ( $\mathbf{1}$ and $\mathbf{3}$ ) have a trans configuration. We believe that the trans is also the most stable isomer for $\mathbf{2}$ and $\mathbf{4}$ although we have no strong evidence for this. The electronic spectra (vide infra) of the bis-diamine complexes did exhibit bands with low molar absorptivities, typical of Laporte-forbidden ligand field transitions. This suggests that the $\left[\mathrm{VCl}_{2}(\mathrm{dmeda})_{2}\right](\mathbf{2})$ and $\left[\mathrm{VCl}_{2}(\text { dieda })_{2}\right]$ (4) molecules have a centre of inversion, a symmetry element already identified in the X-ray structures of the tmeda (1) and deeda (3) analogues.

The route to the mononuclear compounds was based on the reaction of the binuclear complex $\left[\mathrm{V}_{2} \mathrm{Cl}_{3} \text { (thf) }\right]_{6}$ $\left[\mathrm{Zn}_{2} \mathrm{Cl}_{6}\right]$ with an excess of the diamine in boiling thf. It works quite well for all diamines except for teeda, dtbeda and dfeda. Attempts to isolate the mononuclear complex with teeda using this synthetic route failed, and, to our surprise, the only product isolated was the more stable trinuclear complex $\left[\mathrm{V}_{3}(\mu-\mathrm{Cl})\left(\mu_{3}-\mathrm{Cl}\right)_{2}(\text { teeda })_{3}\right] \mathrm{Cl}$. Steric demands increase from dmeda to dtbeda and dfeda. Dtbeda imposes such a steric hindrance that only one diamine binds to $\mathrm{V}^{\mathrm{II}}$ affording $\left[\mathrm{VCl}_{2}(\mathrm{dtbeda})(\text { thf })_{2}\right]$ (5), while dfeda is too large for a stable bond to form.

Three preparative routes have been described for the trinuclear species, $\left.\left[\mathrm{M}_{3}^{\mathrm{II}} \mathrm{X}_{5} \text { (tmeda }\right)_{3}\right]^{+}\left(\mathrm{M}^{\mathrm{II}}=\mathrm{V}, \mathrm{Ti}, \mathrm{Fe}, \mathrm{Co}\right.$ or $\mathrm{Ni}$; $\mathrm{X}$ halide and/or hydroxide). The first has been described as involving a disproportionation. ${ }^{4}$ The second seem to involve halide and perhaps diamine dissociation. ${ }^{4,17}$ and the third is the monomer/dimer interaction (Scheme 2). ${ }^{18}$ However, no clear mechanistic data are available. All that is sure is that the halide and diamine loss which generate the trimer are reversible in at least one case, and one can easily envisage how halide with or without diamine dissociation could be a controlling step in all three systems. Whatever the case, since loss of both halide and diamine must be involved somewhere the strengths of the $\mathrm{M}-\mathrm{Cl}$ and $\mathrm{M}-\mathrm{N}$ bonds should influence the ease of trimer formation.

The third route allows better control of the reaction pathway than the other approaches, avoiding the formation of undesired redox reaction products. We believe this may also be useful for the preparation of mixed-metal triangulo complexes. $^{18}$

The successful synthesis of the trinuclear $\left[\mathrm{V}_{3} \mathrm{Cl}_{5}\right.$ (diamine) $\left.)_{3}\right]\left[\mathrm{B}\left(\mathrm{C}_{6} \mathrm{H}_{5}\right)_{4}\right]$, using either one of the last two methods, depends on the diamine. This was the conclusion we drew based in our attempts to prepare the trinuclear complexes from $\left[\mathrm{VCl}_{2}(\mathrm{dmeda})_{2}\right]$ or $\left[\mathrm{VCl}_{2}(\text { deeda })_{2}\right]$. To explain this, we note that the assembly from $\left.\left[\mathrm{VCl}_{2} \text { (diamine) }\right)_{2}\right]$ requires three equivalents of the diamine to be lost from the reaction mixture for each equivalent of the triangular cation formed (Scheme 1). ${ }^{4}$ In the route we describe here, the formation of $\left.\left[\mathrm{M}_{3} \mathrm{Cl}_{5} \text { (diamine) }\right)_{3}\right]^{+}$also depends on the transfer of one equivalent of the diamine from $\left[\mathrm{MCl}_{2} \text { (diamine) }\right)_{2}$ to a second vanadium centre (Scheme 2).

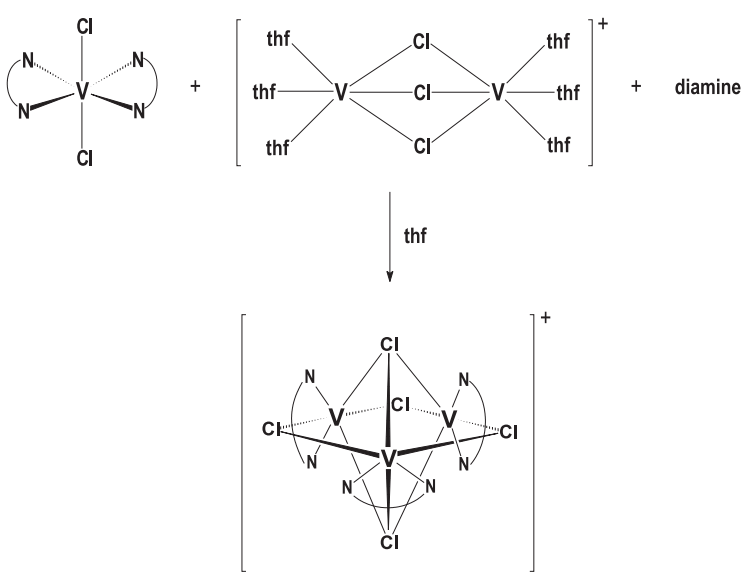

Scheme 2

Our attempts to synthesise the mononuclear $\left.\left[\mathrm{VCl}_{2} \text { (teeda) }\right)_{2}\right]$ from the reaction of $\left[\mathrm{V}_{2} \mathrm{Cl}_{3}(\mathrm{thf})_{6}\right]_{2}\left[\mathrm{Zn}_{2} \mathrm{Cl}_{6}\right]$ with an excess of teeda always led to the trinuclear $\left[\mathrm{V}_{3}(\mu-\mathrm{Cl})_{2}\left(\mu_{3}-\mathrm{Cl}\right)_{2}(\text { teeda })_{3}\right] \mathrm{Cl}, 7$, as the only product isolated. This suggests that teeda binds very weakly in $\left[\mathrm{VCl}_{2}\right.$ (teeda) ${ }_{2}$. The mass spectrum of 7 exhibited a signal at $\mathrm{m} / z=846$ assigned to the molecular ion, $\left[\mathrm{V}_{3}(\mu-\mathrm{Cl})_{3}\left(\mu_{3}-\mathrm{Cl}\right)_{2}(\text { teeda })_{3}\right]^{+}$, with an intensity $90 \%$ of that of the most abundant ion, confirming that this species is very stable in the gas phase. 
Compare this result with an intensity of $20 \%$ for $\left[\mathrm{V}_{3}(\mu\right.$ $\left.\mathrm{Cl})_{3}\left(\mu_{3}-\mathrm{Cl}\right)_{2}(\mathrm{tmeda})_{3}\right]^{+}$.

In the case of deeda, we were able to isolate a light blue powder in the attempt to produce $\left[\mathrm{V}_{3} \mathrm{Cl}_{5}(\text { deeda })_{3}\right]\left[\mathrm{B}\left(\mathrm{C}_{6} \mathrm{H}_{5}\right)_{4}\right]$ (8). The product proved to be extremely unstable and air-sensitive and turned deep purple within a few minutes, even under strict inert atmosphere conditions. This was reproducible.
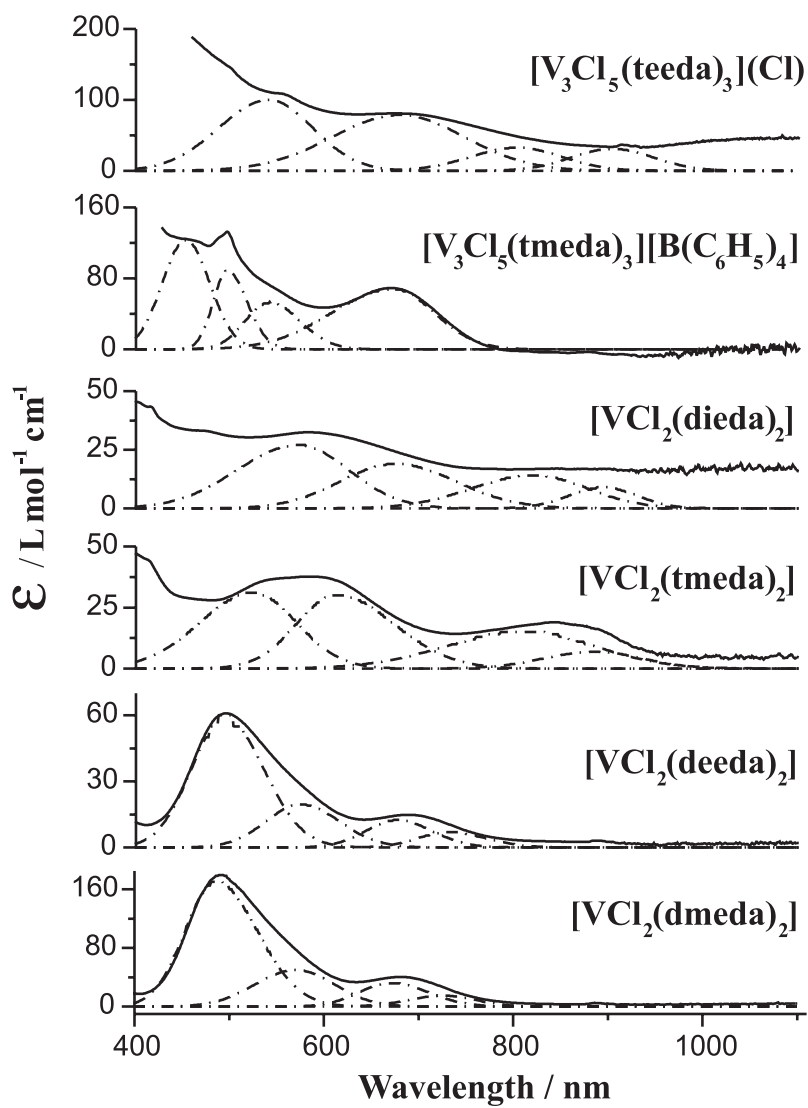

Figure 2. UV-visible spectra of the vanadium(II)-diamine complexes in thf solution.

\section{Electronic spectroscopy}

Table 4 contains a summary of the UV-Visible spectra of the mono- and tri-nuclear complexes. The electronic spectra of the mononuclear complexes show bands mainly in the visible range and the very low intensities observed are consistent with these being d-d transitions (Figure 2). The splitting showed by the bigaussian analysis confirms low symmetry around the vanadium(II). Therefore the spectra were rationalised on the basis of $\mathrm{D}_{4 \mathrm{~h}}$ symmetry and the main bands were assigned as ${ }^{4} \mathrm{~B}_{1 \mathrm{~g}} \rightarrow{ }^{4} \mathrm{~B}_{2 \mathrm{~g}} ;{ }^{4} \mathrm{~B}_{1 \mathrm{~g}} \rightarrow{ }^{4} \mathrm{E}_{\mathrm{g}}(1)$; ${ }^{4} \mathrm{~B}_{1 \mathrm{~g}} \rightarrow{ }^{4} \mathrm{~A}_{2 \mathrm{~g}} ;{ }^{4} \mathrm{~B}_{1 \mathrm{~g}} \rightarrow{ }^{4} \mathrm{E}_{\mathrm{g}}(2)$ from the lowest to the highest energy transitions. The assignment of the terms ${ }^{4} \mathrm{E}_{\mathrm{g}}(1)$ and ${ }^{4} \mathrm{E}_{\mathrm{g}}(2)$ higher in energy than ${ }^{4} \mathrm{~B}_{2 \mathrm{~g}}$ and ${ }^{4} \mathrm{~A}_{2 \mathrm{~g}}$, respectively, was based on the relative intensities. In the cases reported here, the ${ }^{4} \mathrm{E}_{\mathrm{g}}$ component of both splittings are more intense.

These assignments are consistent with the negative values of the sppliting parameters $\mathrm{D}_{\mathrm{t}}$ and $\delta \sigma(\delta \sigma$ is from the MacClure's Molecular Orbital Model). ${ }^{19}$ The same argument was used by Baker and Phillipis ${ }^{19}$ for the series trans- $\left[\mathrm{Cr}(\mathrm{en})_{2} \mathrm{X}_{2}\right]^{\mathrm{n}+}$. $\mathrm{D}_{\mathrm{t}}$ was determined from the splitting of the first excited term, ${ }^{1} \mathrm{~T}_{2 \mathrm{~g}}$. A $\mathrm{D}_{4 \mathrm{~h}}$ symmetry was also assigned to $\left[\mathrm{VCl}_{2}(\text { ethanol })_{4}\right]$ and $\left.\left[\mathrm{VCl}_{2} \text { (pyrazine }\right)_{4}\right]$ based on the number of bands observed in the visible spectra. ${ }^{20}$

As the energies of ${ }^{4} \mathrm{~B}_{1 \mathrm{~g}} \rightarrow{ }^{4} \mathrm{~B}_{2 \mathrm{~g}}$ corresponds exactly to the value of $10 \mathrm{Dq}$, the order of decreasing crystal field splitting is: dmeda $<$ deeda $<$ tmeda $<$ dieda. This conclusion is in agreement with the values of $\mathrm{D}_{\mathrm{t}}$ and $\delta \sigma$ (Table 4).

\section{Infrared spectroscopy}

Table 4 also presents the V-N stretching frequencies for the $\left[\mathrm{VCl}_{2}(\text { diamine })_{2}\right]$ complexes. It can be seen that the values agrees with the crystal field analysis, with the $v(\mathrm{~V}-\mathrm{N})$ in the order: dmeda $>$ deeda $>$ tmeda $>$ dieda.

Table 4. Spectroscopic data for vanadium diamine complexes

\begin{tabular}{|c|c|c|c|c|c|c|c|c|}
\hline Complex & Color & Wavelength, nm & $\mathrm{D}_{\mathrm{q}}, \mathrm{cm}^{-1 \mathrm{~b}}$ & $\mathrm{D}_{\mathrm{t}}, \mathrm{cm}^{-1} \mathrm{~b}$ & $\mathrm{D}_{\mathrm{s}}, \mathrm{cm}^{-1 \mathrm{~b}}$ & $\delta \sigma, \mathrm{cm}^{-1 \mathrm{~b}}$ & MOE, $\mathrm{kJ}^{\mathrm{c}}$ & $v(\mathrm{~V}-\mathrm{N})$ \\
\hline$\left[\mathrm{VCl}_{2}(\mathrm{dmeda})_{2}\right]$ & pink & $727,671,570,486^{\mathrm{a}}$ & 1376 & -130 & 534 & -475 & -1142 & 424 \\
\hline$\left[\mathrm{VCl}_{2}(\text { deeda })_{2}\right]$ & purple & $730,676,574,494^{a}$ & 1370 & -125 & 496 & -433 & -1128 & 395 \\
\hline$\left[\mathrm{VCl}_{2}(\mathrm{tmeda})_{2}\right]$ & blue & $890,810,612,524^{a}$ & 1130 & -120 & 482 & -423 & -1124 & 376 \\
\hline$\left[\mathrm{VCl}_{2}(\text { dieda })_{2}\right]$ & violet & $894,820,674,571^{\mathrm{a}}$ & 1119 & -115 & 469 & -415 & -1115 & 370 \\
\hline$\left[\mathrm{V}_{3} \mathrm{Cl}_{5}(\text { tmeda })_{3}\right]^{+}$ & green & $610,461,410,360^{\mathrm{d}}$ & - & - & & & - & - \\
\hline$\left[\mathrm{V}_{3} \mathrm{Cl}_{5} \text { (teeda) }{ }_{3}\right]^{+}$ & light-green & $900,765,630,476^{\mathrm{d}}$ & - & - & & & - & - \\
\hline
\end{tabular}

${ }^{a}$ Spectra taken in thf solution. Assignments for the dipole forbidden transitions, from the lowest to the highest energy states are: ${ }^{4} \mathrm{~B}_{1 \mathrm{~g}} \rightarrow{ }^{4} \mathrm{~B}_{2 \mathrm{~g}}\left(v_{1}\right)$; ${ }^{4} \mathrm{~B}_{1 \mathrm{~g}} \rightarrow{ }^{4} \mathrm{E}_{\mathrm{g}}(1)\left(v_{2}\right) ;{ }^{4} \mathrm{~B}_{1 \mathrm{~g}} \rightarrow{ }^{4} \mathrm{~A}_{2 \mathrm{~g}} ;\left(v_{3}\right){ }^{4} \mathrm{~B}_{1 \mathrm{~g}} \rightarrow{ }^{4} \mathrm{E}_{\mathrm{g}}(2)\left(v_{4}\right) ;{ }^{\mathrm{b}}$ Calculated according ref. 19: $10 \mathrm{D}_{\mathrm{q}}=\mathrm{E}\left({ }^{4} \mathrm{~B}_{1 \mathrm{~g}} \rightarrow{ }^{4} \mathrm{~B}_{2 \mathrm{~g}}\right) ; \mathrm{D}_{\mathrm{t}}=4 / 35\left(v_{1}-v_{2}\right) ; \mathrm{D}_{\mathrm{s}}=1 / 6\left[v_{4}-v_{3}+\right.$ $\left.5 / 4 \mathrm{D}_{\mathrm{t}}\right] ; \delta \sigma=1 / 4\left(v_{3}-v_{4}-v_{1}+v_{2}\right) ;{ }^{\mathrm{c}}$ MOE $=$ mean value of the energy of the molecular orbital with the highest diamine contribution in the $\left.\left[\mathrm{VCl}_{2} \text { (diamine) }\right)_{2}\right] ;{ }^{\mathrm{d}}{ }^{4} \mathrm{E} " \rightarrow{ }^{4} \mathrm{E},,{ }^{4} \mathrm{E} " \rightarrow{ }^{4} \mathrm{~A}_{2},{ }^{4} \mathrm{E} " \rightarrow{ }^{4} \mathrm{E} ",{ }^{4} \mathrm{E} " \rightarrow{ }^{4} \mathrm{~A}_{2}^{\prime},{ }^{4} \mathrm{E} " \rightarrow{ }^{4} \mathrm{E} "$ (see text for discussion). 


\section{Thermogravimetric analysis}

The thermal behaviour of $\left[\mathrm{VCl}_{2}(\text { diamine })_{2}\right]$ depends on the nature of the diamine as seen in Table 5. Figure 3 shows a typical thermogravimetric behaviour of the series. There is a clear and good correlation between the order of ligand field and the diamine- $\mathrm{V}$ bond strength determined from the spectroscopic data and the temperature for dissociation of the first diamine. The order is: dmeda $\left(375^{\circ} \mathrm{C}\right)>\operatorname{deeda}\left(207{ }^{\circ} \mathrm{C}\right)>\operatorname{tmeda}\left(173{ }^{\circ} \mathrm{C}\right)>$ dieda $\left(150{ }^{\circ} \mathrm{C}\right)$. The results give strong support to the relative stability of $\left.\left[\mathrm{VCl}_{2} \text { (diamine }\right)_{2}\right]$ complexes obtained from the crystal field analysis.

It is significant that the $\left[\mathrm{VCl}_{2}(\mathrm{dmeda})_{2}\right]$ loses chloride before the dissociation of the diamine, consistent with the very strong vanadium-dmeda bond. Also, we notice close temperatures for the dissociation of tmeda and dieda, which suggests similar coordination capacities. This was also pointed out from the spectroscopic data.

Table 5. Thermogravimetric data for vanadium diamine complexes. The entries are \% of weight loss / temperature in ${ }^{\circ} \mathrm{C}$

\begin{tabular}{lllll}
\hline loss of / diamine & dmeda & deeda & tmeda & dieda \\
\hline $1^{\text {st }}$ diamine & $30,0 / 375$ & $28,4 / 207$ & $23,0 / 173$ & $27,5 / 150$ \\
$2^{\text {nd }}$ diamine & $*$ & $34,5 / 296$ & $30,0 / 252$ & $30,0 / 445$ \\
$1^{\text {st }}$ chloride & $10,6 / 175$ & $13,2 / 548$ & $12,0 / 343$ & $8 / 220$ \\
$2^{\text {nd }}$ chloride & $13,8 / 277$ & $*$ & $11,5 / 516$ & $10,0 / 270$ \\
\hline
\end{tabular}

* undetermined.

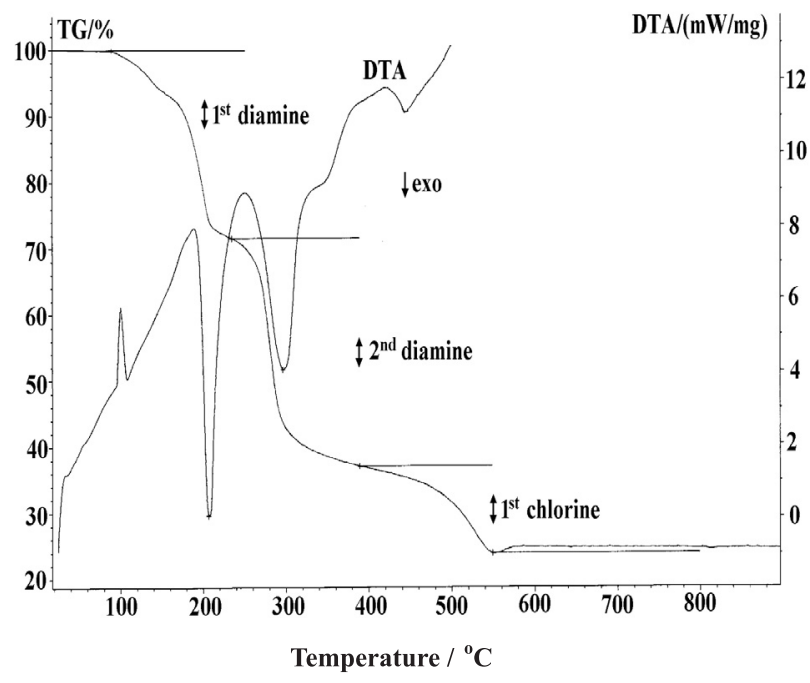

Figure 3. TG and DTA of $\left[\mathrm{VCl}_{2}(\text { deeda })_{2}\right]$

\section{INDO/S}

Calculated energies of the molecular orbitals with the highest contribution of the diamine (MOE) are presented in Table 4. It is expected that the stronger the vanadium-diamine interaction, the more negative would be MOE values. Therefore, MOE also agrees with the UVvis, infrared and the thermogravimetric results.

If the HOMO is the donor orbital of the diamine, containing the nitrogen lone pair, then its energy will probably parallel its basicity towards the proton. The basicity towards a transition metal ion would also depend upon other factors, such as the bulk of the nitrogen substituents and the interaction with the other ligands on the metal ion. In addition, the degree of $\mathrm{V}-\mathrm{N} \sigma$-overlap will depend on the closeness in energy of the HOMO to the metal acceptor orbitals. The HOMOs of the free diamines are in the order: dmeda, -907; deeda, -897; tmeda, -878; teeda, -859 and dieda, $-825 \mathrm{~kJ}$, which accords with our inferences concerning the relative stability of the complexes $\left[\mathrm{VCl}_{2}(\text { diamine })_{2}\right]$. The complex with teeda could not be prepared.

The UV-vis spectra of the trinuclear complexes, $\left[\mathrm{VX}_{5}(\text { diamine })_{3}\right]^{+}$were interpreted on the basis of $\mathrm{D}_{3 \mathrm{~h}}$ symmetry, and the four bands observed were assigned to the transitions, ${ }^{4} \mathrm{E} " \rightarrow{ }^{4} \mathrm{E},,{ }^{4} \mathrm{E} " \rightarrow{ }^{4} \mathrm{~A}_{2}{ }^{\prime},{ }^{4} \mathrm{E} "{ }^{\prime} \rightarrow{ }^{4} \mathrm{E},,{ }^{4} \mathrm{E} "{ }^{4} \mathrm{~A}_{2}{ }^{\prime}$, ${ }^{4} \mathrm{E} " \rightarrow{ }^{4} \mathrm{E}$ ' (Table 4)

\section{Conclusions}

The synthetic work, combined with the spectroscopic data and calculated energies for the appropriate molecular orbitals, has allowed the first systematic evaluation of the relative stability in the $\left.\left[\mathrm{VCl}_{2} \text { (diamine) }\right)_{2}\right]$ and the $\left.\left[\mathrm{V}_{3} \mathrm{Cl}_{5} \text { (diamine }\right)_{3}\right]^{+}$complexes. In addition, a facile and rational new route for the preparation of the trinuclear compounds was presented.

Our findings suggest that although the most basic, teeda has the greatest steric demands among the diamines employed in this work, resulting in a smaller coordination capability. On the other hand, although the least basic, dmeda offers a small steric hindrance and produced higher crystal field stabilisation energies. This behaviour was also observed when we compared deeda, dieda and tmeda.

The structures of comparable mononuclear compounds (1 and 3) revealed a shorter and, therefore, stronger vanadium-nitrogen bond for the less basic but also less bulky deeda (Table 3 ).

Considering the spectroscopic data, there is a real though small dependence of the magnitude of the electronic transition energies on the nature of the diamine. There is a clear and good correlation between the UVvisible, infrared and thermogravimetric results with the calculated energies of the molecular orbitals of the related diamines and also the stability of the mononuclear 
complexes. However, the stability of all compounds results from synergistic effects, which include electronic and stereochemical aspects. Any attempt to make a single-parameter analysis must be taken with caution.

In all complexes $\left.\left[\mathrm{VCl}_{2} \text { (diamine) }\right)_{2}\right]$, the only bonding in the equatorial plane is the $\sigma$-type. Additional bonding is supplied by weak axial interactions with chlorides, most likely $\pi$-bonding with the vanadium $\mathrm{d}_{\mathrm{xz}}$ and $\mathrm{d}_{\mathrm{yz}}$ orbitals. The stronger the V-diamine bonding, the weaker should be the corresponding $\mathrm{V}-\mathrm{Cl}$ bond as can be seen by the crystallographic data in Table 3. This may have a major influence on the lability of chloride in substitution reactions.

The new route to the synthesis of $\left[\mathrm{V}_{3}(\mu-\mathrm{Cl})_{3}\left(\mu_{3}-\right.\right.$ $\mathrm{Cl})_{2}$ (diamine $\left.)_{3}\right]^{+}$minimises the formation of sub-products and contributes to a better understanding of self-assembly mechanisms.

\section{Supplementary Material}

Crystallographic data (excluding structure factors) for the structure in this paper have been deposited with the Cambridge Crystallographic Data Centre as supplementary publication $n^{\circ}$ CCDC 189635. Copies of the data can be obtained, free of charge via www.ccdc.cam.ac.uk/conts/ retrieving.html (or from the Cambridge Crystallographic Data Centre, CCDC, 12 Union Road, Cambridge CB2 1EZ, UK; fax: +44 1223 336033; or e-mail: deposit@ccdc.cam.ac.uk).

\section{Acknowledgements}

This work was supported by Brazilian PRONEX Program (Contract Number 41.96.0884.00), which we gratefully acknowledge. We thank Dr. A. Abdul Sada (CPES, UK) for the mass spectra, Mr. Cesar A. Tischer (DBq-UFPR, Brazil) for the NMR spectra and Prof. Dr. Koiti Araki (IQUSP, Brazil) for the bigaussian analysis program. A.C.N. thanks the Brazilian Research Council (CNPq) for a research fellowship.

\section{References}

1. Robson, R. L.; Eady, R. R.; Richardson, T. H.; Miller, R. W.; Hawkins, M.; Postgate, J. R.; Nature (London) 1986, 322, 388; Eady, R. R.; Leigh, G. J.; J. Chem. Soc., Dalton Trans. 1994, 2739; Rehder, D. J. Inorg. Biochem. 2000, 80, 133; Einsle, O.; Tezcan, F. A.; Andrade, S. L. A.; Schmid, B.; Yoshida, M.; Howard, J. B.; Rees, D. C.; Science 2002, 297, 1696; Smith, B. E; Science 2002, 297, 1654.
2. Nunes, F. S.; Raimondi, A. C.; Niedwieski, A. C.; Quim. Nova, in press; Leigh, G. J.; Science 1998, 279, 506; Bazhenova, T. A.; Shilov, A. E.; Coord. Chem. Rev. 1995, 144, 69; Fryzuk, M. D.; Johnson, S. A.; Coord. Chem. Rev. 2000, 200, 379.

3. Edema, J. J. H.; Stauthamer, W.; van Bolhuis, F.; Gambarotta, S.; Smeets, W. J. J.; Spek, A. L.; Inorg. Chem. 1990, 29, 1302.

4. Edema, J. J. H.; Meetsma, A.; Gambarotta, S.; J. Chem. Soc., Chem. Commun. 1990, 951; Edema, J. J. H.; Duchateau, R.; Gambarotta, S.; Bensimon, C.; Inorg. Chem. 1991, 30, 3585; Hughes, D. L.; Larkworthy, L. F.; Leigh, G. J.; McGarry, C. J.; Sanders, J. R.; Smith, G. J.; de Souza, J. S.; J. Chem. Soc., Chem. Commun. 1994, 2137; Hitchcock, P. B.; Hughes, D. L.; Larkworthy, L. F.; Leigh, G. J.; Marmion, C. J.; Sanders, J. R.; Smith, G. J.; de Souza, J. S.; J. Chem. Soc., Dalton Trans. 1997, 1127.

5. Perrin, D. D.; Armarego, W. L. F.; Purification of Laboratory Chemicals, $3^{\text {rd }}$ ed., Butterworth Heenemann: Oxford, 1997.

6. Earnshaw, A.; Introduction to Magnetochemistry, Academic Press: London, 1968.

7. Ridley, J. E.; Zerner, M. C.; Theoret. Chim. Acta (Berlin) 1973 , 32, 111; Bacon, A. D.; Zerner, M. C.; Theoret. Chim. Acta (Berlin) 1979, 53, 21; Zerner, M. C.; Loew, G. H.; Kirchner, R. F.; Mueller-Westerhoff, U. T.; J. Am. Chem. Soc. 1980, 102, 589; Anderson, W. P.; Edwards, W.D.; Zerner, M. C.; Inorg. Chem. 1986, 25, 2728; Anderson, W. P.; Cundari, T.R.; Drago, R.S.; Zerner, M. C.; Inorg. Chem. 1990, 29, 1; Anderson, W. P.; Cundari, T.R.; Zerner, M. C.; Int. J. Quantum Chem. 1991, 39, 31; Cory, M. G.; Kostlmeyer, S.; Kotzian, M.; Rosch, N.; Zerner, M. C.; J. Chem. Phys. 1994, 100, 1353.

8. Niedwieski, A. C.; Hitchcock, P. B.; Leigh, G. J.; Soares, J. F; Nunes, F. S.; da Motta, J. D.; Int J. Quant. Chem. 2002, 88, 245 .

9. Stavrev, K. K.; Zerner, M. C.; Chem. Phys. Lett. 1996, 263, 667; O’Brien, T. A.; Albert, K.; Zerner, M. C.; J. Chem. Phys. 2000,112, 3192.

10. Edwards, W. D.; Zerner, M. C.; Theoret. Chim. Acta (Berlin) 1987, 72, 347.

11. Zerner, M. C.; Int. J. Quantum Chem. 1989, 35, 567.

12. Da Motta, J. D.; Zerner, M. C., Int. J. Quantum Chem. 2000 , $81,187$.

13. Farrugia, L. J.; J. Appl. Cryst. 1999, 32, 837; Farrugia, L. J.; J. Appl. Cryst. 1997, 30, 565.

14. Sheldrick, G. M.; SHELXL-97: Program for Crystal Structure Refinement; University of Göttingen, Germany, 1997.

15. Bouma, R. J.; Teuben, J. H.; Beukema, W. R.; Bansemer, R. L.; Huffman, J. C.; Caulton, K. G.; Inorg. Chem., 1984, 23, 2715; Cotton, F. A.; Duraj, S. A.; Extine, M. W.; Lewis, G. E.; Roth, W. J.; Schmulbach, C. D.; J. Chem. Soc., Chem. Commun. 1983, 1377. 
16. Cotton, F. A.; Duraj, S. A.; Roth, W. J.; Inorg. Chem. 1985, 24 913.

17. Davies, S. C.; Hughes, D. L.; Leigh, G.J.; Sanders, J. R.; de Souza, J. S.; J. Chem. Soc., Dalton Trans. 1997, 1981; Sobota, P.; Utko, J.; Szafert, S.; Janas, Z.; Glowiak, T.; J. Chem. Soc., Dalton Trans. 1996, 3469; Handley, D. A.; Hitchcock, P. B.; Leigh, G. J.; Inorg. Chim. Acta 2001, 314, 1.

18. Niedwieski, A. C.; Raimondi, A. C.; Hughes, D. L.; Leigh, G. J.; Nunes, F. S; Soares, J. F. In Nitrogen Fixation: From Molecules to Crop Productivity; Pedrosa, F.; Hungria, M.; Yates, G.; Newton, W. E. eds.; Kluwer Academic Publishers: Dordrecht, 2000, 62; Evans, D. J.; Hitchcook, P. B.; Hughes, D. L.; Leigh, G. J.; Nicholson, B. H.; Niedwieski, A. C.; Nunes, F. S.; Soares, J. F. Inorg. Chim. Acta, 2001, 319, 147.
19. Baker, Jr., W. A. ; Phillips, M. G.; Inorg. Chem. 1966, 5, 1042 .

20. Larkworthy, L. F.; O’Donoghue, M. W.; Inorg. Chim. Acta 1983, 71, 81 .

21. Lever, A. B. P.; Inorganic Electronic Spectroscopy, Elsevier: Amsterdam, 1964.

Received: October 28, 2002

Published on the web: August 1, 2003 